UDK 1Suárez, F.

$111: 27-789.5]: 274$

274:[111:27-789.5

doi: $10.31337 / \mathrm{oz} .73 .2 .4$

Pregledni rad

Primljeno 1.3.2018.

Prihvaćeno 27.6.2018.

\title{
Utjecaj Francisca Suáreza na protestantsku skolastiku
}

Josip Talanga*

\begin{abstract}
Sažetak
Suárezove Metafizičke disputacije postigle su nevjerojatan uspjeh. Popularnost je bila osobito velika u reformacijskim sredinama. Osim Melanchthonova utjecaja, u prvoj fazi prevladavao je utjecaj humanista i Ramusa, no na prijelazu iz 16. $u$ 17. stoljeće na protestantskim se sveučilištima obnavlja aristotelizam. Kada je 1600. prvi put u Njemačkoj tiskano Suárezovo djelo Metafizičke disputacije, kalvinistički i luteranski filozofi i teolozi potpuno su se otvorili prema isusovačkoj metafizici. Bez Suárezova utjecaja nezamisliva je protestantska Schulmetaphysik. Glavni razlog recepcije bila je potreba za metafizikom u teološkim raspravama. Lutherovo načelo sola scriptura bilo je dostatno za čvrstoću vjere, ali je u teološkim kontroverzama tražilo metafizičke dopune. Suárezov priručnik metafizike nametnuo se svim kršćanskim konfesijama kao dobro polazište za rasprave. Pod utjecajem njegovih ideja utemeljili su kalvinisti Rudolf Göckel $i$ Clemens Timpler epistemološki orijentiranu metafiziku koja se primarno bavi mislivim kao mislivim, a biće se shvaća kao podudarno s mislivim. S druge strane Christoph Scheibler presudno je utjecao na luteransku tradiciju koja metafiziku shvaća kao znanost o biću kao biću, ali istovremeno podjelu bića obrazlaže epistemološki. Višestruke varijacije između tih dvaju stajališta postaju tipične za njemačku Schulmetaphysik.

Ključne riječi: protestantska skolastika, Schulmetaphysik, Francisco Suárez, ontologija, povijest metafizike, 16. stoljeće, 17. stoljeće
\end{abstract}

\section{Uvod}

Kao tvorac prvog sustavnog metafizičkog djela Disputationes metaphysicae Suárez je prije svega bio zainteresiran za opća metafizička pitanja, ono što je nakon Christiana Wolffa bila tema ontologije. ${ }^{1}$ Po njegovu shvaćanju metafizi-

* Prof. dr. sc. Josip Talanga, Fakultet filozofije i religijskih znanosti Sveučilišta u Zagrebu. Adresa: Jordanovac 110, 10000 Zagreb, Hrvatska. E-pošta: j.talanga@ffrz.hr

1 Neologizam ontologia pojavljuje se prvi put kod Jacoba Lorharda (1561.-1609.), kalvinističkog filozofa i pedagoga, ravnatelja gimnazije u St. Gallenu (Švicarska), u djelu Ogdoas scholastica 
ka se bavi bićem kao realnim bićem (ens in quantum ens reale, DM 1.1.26; vol. 25, 11). Osim 29. i 30. disputacije, koje se bave beskonačnim ili prvim bićem, preostali dio monumentalnog djela posvećen je ontološkim problemima. Nakon prve dvije meditacije, u kojima Suárez objašnjava narav metafizike i pojam bića, idućih devet disputacija bavi se transcendentalnim odredbama bića, potom je petnaestak disputacija posvećeno uzrocima bića, a treća najveća cjelina, ukupno 22 disputacije, bavi se supstancijom i akcidentima te kategorijama kao kategorijama akcidenta. Posljednja, 54. disputacija tematizira nebiće kao ens rationis. Nužno je da postoje bića razuma (entia rationis dari oportet, DM 46.1.4; vol. 26, 754), iako takva bića nisu ni istinska ni realna. No ona ipak imaju esse obiectivum (DM 54.2.3; vol. 26, 1019) koje mora biti uzrokovano realnim bićem (esse reale). Zapravo je intelekt eficijentni uzrok bića razuma.

\section{Utjecaj Suárezove metafizike i protestantska potreba za metafizikom}

Suárezove Metafizičke disputacije postigle su nevjerojatan uspjeh diljem kontinenta. Velik broj pretisaka nastao je u nekoliko desetljeća, popularnost je bila osobito velika u reformacijskim sredinama. Znamo da je Leibniz (1646.-1716.) cijenio predstavnike visoke skolastike, ali ih je površno poznavao. No Suárezov priručnik metafizike, kao student, kao sedamnaestogodišnjak, čitao je kao neki roman (Leibniz, 1875, 198; usp. Jasper, 1898; Rintelen, 1903, 173). Utjecaj španjolske skolastike na sjevernu Europu počeo je već generaciju prije Suáreza, a išao je preko sveučilišta u Lyonu, Antwerpenu te Mainzu i Kölnu, osobito tiskanjem njihovih djela. Ni kalvini ni luterani nisu si mogli priuštiti stav Catholica non leguntur, jer najcjenjeniji protestantski autoritet Philipp Melanchthon oskudno je obrađivao metafizičke teme, ali ipak nije bio zatvoren prema učenoj literaturi iz katoličke sredine.

Na prijelazu iz 16. u 17. stoljeće na protestantskim se sveučilištima obnavlja aristotelizam, napose uz pomoć komentatora sa sveučilišta u Coimbri (takozvani Conimbricenses) i Suárezove metafizike. Između 1520. i 1560. na protestantskim sveučilištima gotovo su nestale katedre za metafiziku, a objavljena djela s metafizičkom tematikom vrlo su rijetka ili krajnje neambiciozna (Devaux i La-

(1606.). Nalazimo ju na naslovnici kao oznaku za posljednje, osmo područje (dakle u skladu s naslovom djela „Osam školskih umijeća“), koje je posvećeno metafizici: metaphysica seu ontologia, dakle uvodi se kao istoznačnica za termin metafizika. Ranije se vjerovalo da je taj termin uveo Rudolf Göckel (1547.-1628.), poznatiji pod latinskim imenom Rodolphus Goclenius, u svojem

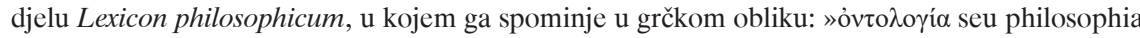
de ente« (Göckel, 1613, 16). Vjerojatno je Göckel u izravnom osobnom kontaktu preuzeo termin od Lorharda jer je Lorhard 1607. kratko vrijeme, oko pola godine, bio profesor teologije u Marburgu, gdje je Göckel bio profesor logike, etike i matematike. Tijekom 17. stoljeća termin ontologia rabi se u generičkom smislu. Tek kasnije ulazi u širu uporabu kao naziv koji pokriva područje opće metafizike, osobito pod utjecajem djela Christiana Wolffa Philosophia prima sive ontologia (1730.). Opširno o tome u: Devaux i Lamanna, 2009, 174. 
manna, 2009, 175). Uz Lutherovu netrpeljivost prema Aristotelu² Melanchthon je svojim eklektičkim, ali načelno aristotelovskim filozofskim djelima održao interes za filozofiju među reformatorima. Prva generacija njemačkih reformatora bila je pod posebnim utjecajem paulinske teologije. Bili su svjesni da je apostol Pavao poznavao i koristio dijalektičku argumentaciju koju je stekao svojim filozofskim, napose stoičkim obrazovanjem, pa nije imalo smisla tumačiti paulinsku teologiju bez dijalektike (Petersen, 1921, 279). Zato su poticali bavljenje Aristotelovom logikom. ${ }^{3} \mathrm{U}$ to vrijeme prvi su reformatori bili dosta pod utjecajem europskoga humanizma, ali i talijanske renesanse, posebno je bio utjecajan Giacoma Zabarelle (1533.-1589.), koji je aristotelizam sveo na logiku. U prvoj fazi proširenog bavljenja Aristotelovom filozofijom Petrus Ramus (Pierre de la Ramée, 1515.-1572.) potisnuo je Melanchthonov utjecaj. ${ }^{4}$ No početkom 17. stoljeća na luteranskim sveučilištima zastupljena je metafizika koja je očito bila pod isusovačkim utjecajem. ${ }^{5}$ Dakle, poslije Melanchthona i ramističke faze luteranska se ortodoksija u filozofskom pogledu oslanja direktno na aristotelizam, pod neupitnim utjecajem Suáreza.

Koji su razlozi da su luteranski i kalvinistički teolozi u metafizici postali sljedbenici Suáreza? Primjerice povjesničar protestantske dogmatike Wilhelm Gaß kaže da protestanti početkom 17. stoljeća nisu imali nikakvo veće sustavnije djelo iz metafizike, pa su zato usvojili Suárezovu metafiziku (Gaß, 1854, 185). No to je izazvalo reakciju Ernsta Tröltscha, koji tvrdi da su se protestanti već ranije, $u$ posljednjoj četvrtini 16. stoljeća, počeli intenzivno baviti Aristotelovom metafizikom (Tröltsch, 1891, 105). Da su se protestantski filozofi bavili Aristotelom prije 1600. može se potkrijepiti navođenjem niza komentara Aristotelovih djela. Međutim do 1600. protestantski autori nisu objavili nijedan potpuni komentar Aristotelove Metafizike. Upravo te godine tiskano je u Mainzu prvo izdanje Suárezovih Metafizičkih disputacija na području Njemačke. Editio princeps bila je samo tri godine ranije (1597.). Do 1630. bilo je u Mainzu i Kölnu ukupno šest izdanja (Mainz 1600., 1605., 1614. i 1630; Köln 1608. i 1614.). Očito su neke vanjske okolnosti, naime nedostatak protestantskih djela o metafizici i pojava iznimnog metafizičkog djela Francisca Suáreza, utjecale na recepciju isusovačke metafizike kako na reformiranim (kalvinskim) tako i na luteranskim sveučilištima. No pi-

2 U svojim Tischgespräche nazivao ga je Narristoteles. Lutherovo inzistiranje na sola scriptura utjecalo je u toj ranoj fazi na zanemarivanje filozofije kao neke vrste intelektualnog posredovanja u razumijevanju teoloških istina.

3 U tu prvu generaciju možemo ubrojiti i Matiju Vlačića Ilirika (1520.-1575.) s njegovim djelom Paralipomena dialectices (1558.).

4 »The recourse to Ramistic logic was aimed at resolving, with the help of its common tools and rules, some Protestant theological controversies. Ramistic logic thus came to be defended not just by Calvinists, but also by Melanchthonians (the so-called Philippo-Ramists), as well as by some radical Lutherans (Heizo Buscher and Daniel Hofmann)« (Devaux i Lamanna, 2009, 175-176).

5 Kako kaže jedan od prvih povjesničara tzv. ortodoksno-luteranske skolastike (koja je trajala gotovo cijelo 17. stoljeće) Johannes Hermann von Elswich (1684.-1721.): »quod Lojolitis, quos non immerito neo-scholasticos appellaveris, usitatum erat, omnia metaphysicis ut nominant involvere terminis« $(1720,75)$. 
tanje je je li to jedini razlog takve popularnosti Suárezova djela u protestantskoj sredini. Možda postoje i neki dublji, unutrašnji razlozi.

Emil Weber bavio se utjecajem skolastičke filozofije na prominentne teologe tzv. luteranske ortodoksije, a napose je istraživao citiranost skolastičkih filozofa u nekim utjecajnim protestantskim udžbenicima. Tako je kod luterana Jakoba Martinija (1570.-1649.), profesora u Wittenbergu, u njegovu metafizičkom udžbeniku Theorematum metaphysicorum exercitationes (1603.) nabrojao pored 110 citata iz Tome Akvinskoga 67 iz Suáreza te 40 iz Fonsece. ${ }^{6}$ Kod kalvinista Johanna Heinricha Alsteda (1588.-1638.) sa sveučilišta u Herbornu, u njegovoj Metafizici (1613.), uz samo 16 citata iz Tome nalazi 74 citata iz Fonsece i 27 iz Suáreza (Weber, 1907, 56 i 63). Očito je isusovac Petrus Fonseca (odnosno Pedro da Fonseca, 1528.-1599.) već ranije bio utjecajan u protestantskim krugovima, ali ga je postupno istisnuo Suárez.

Ako se traže unutarprotestantski razlozi za povećano bavljenje metafizičkim pitanjima, onda ih prije svega treba tražiti u teološkim raspravama. Potreba za metafizikom vidljiva je već u stalnim dopunama i proširenjima Melanchthonova djela Loci communes. Prvo je izdanje objavljeno još na početku reformacijskoga pokreta 1521. godine. U novim je izdanjima, a posljednje u nizu bilo je 1559., osim jačeg isticanja slobodne volje, sve više uvodio teme iz skolastičke teologije i sve veći broj klasičnih filozofskih pojmova, ali je ipak i dalje čvrsto vjerovao da je za razumijevanje metafizičkih pojmova dovoljna logika. Primjerice Melanchthonov omiljeni učenik David Chytraeus (1530.-1600.) ${ }^{8}$ priča kako Melanchthon Aristotelovu Metafiziku, napose knjigu Delta, smatra prije svega korisnom logičkom i gramatičkom raspravom, iako je ta knjiga zapravo leksikon najvažnijih pojmova iz Aristotelove Metafizike (Petersen, 1921, 280). Slično tomu Petrus Ramus (odnosno Pierre de la Ramée) oskudno je tematizirao metafizička pitanja, pa je njegov povećani utjecaj bio još uvijek vezan za ulogu dijalektike kod prvih reformatora. ${ }^{9}$ No već sljedeće generacije sve više usvajaju Aristotelovu metafiziku kao nezaobilazno sredstvo u teološkim raspravama. Može se reći da se recepcija Suárezove metafizike nastavlja na unutrašnju protestantsku potrebu za metafizikom u teološkim raspravama.

\section{Luteranska i kalvinistička recepcija Suárezove metafizike}

U recepciji klasične metafizike razlikuju se kalvinisti i luterani. Kalvinisti su se od 1560. nadalje raširili po Nizozemskoj i zapadnom dijelu Njemačke. Njihovim utjecajem širio se i ramizam, osebujna filozofija, prije svega logika, koju je razvio kalvinist Pierre de la Ramée (1515.-1572.). Budući da je ubijen za vrijeme Barto-

Odnosi se prije svega na njegov vrlo popularan komentar Aristotelove Metafizike iz 1577. godine. Od izdanja 1543. naslov je promijenjen u Loci praecipui theologici.

Bio je kasnije dugogodišnji profesor u Rostocku. Po uzoru na svojeg učitelja svoje je njemačko prezime (Kochhafe) preveo na grčki i latinizirao.

Prema Petersenu: »tota metaphysica [...] nil habet fere nisi logicum« $(1921,280)$. 
lomejske noći, postao je kao žrtva vrlo prihvatjiv i u luteranskim krugovima. Kalvinisti su metafiziku prvo uveli na svojim gimnazijama (Herborn, Steinfurt, St. Gallen) te potom na sveučilištima koje su kontrolirali (Basel, Heidelberg, Marburg). Također su bili prvi koji su popularizirali isusovačku metafiziku kakvu su razvili na početku Pedro da Fonseca (1528.-1599.) i Benet Perera (1536.-1610.), a potom i Francisco Suárez. Kada je 1600. prvi put u Njemačkoj tiskano Suárezovo djelo Metafizičke disputacije, i luteranski su se filozofi i teolozi potpuno otvorili prema isusovačkoj metafizici (Devaux i Lamanna, 2009, 176). Djelo se nije samo čitalo kao važan filozofski autoritet, nego su se očevidno usvajale mnoge teze koje su ostavile dubok trag u protestantskoj Schulmetaphysik. ${ }^{10}$

\subsection{Daniel Cramer}

Jedan od prvih koji se na nekom protestantskom sveučilištu bavio Aristotelovom Metafizikom bio je Daniel Cramer (1568.-1637.), neko vrijeme profesor logike u Wittenbergu, koji je 1594. u Hannoveru tiskao svoje djelo Isagoge in Metaphysicam Aristotelis, posvećeno astronomu Tychu Brahi, a u kojem prije svega parafrazira Aristotelov tekst i poput Melanchthona potpuno ignorira skolastičku tradiciju komentiranja. Još je ranije Nikolaus Öchslin, poznatiji kao Nicolaus Taurellus (1547.-1606.) objavio svoju metafizičku raspravu Philosophiae triumphus, hoc est metaphysica philosophandi methodus (1573.) te je rehabilitirao metafiziku kao ozbiljno akademko istraživanje. Zastupao je učenje o aktivnom karakteru ljudskog uma i pluralizam supstancija, pa na neki način prefigurira neka Leibnizova shvaćanja, koji ga i citira na nekim mjestima. Međutim, vrlo je zagonetno da Taurellus (Öchslin), za kojega se može reći da je bio ozbiljan i vrlo samostalan filozof, gotovo uopće nije utjecao na kasnije generacije protestantskih pisaca, ali nije ni bilo puno negativnih reakcija, nešto više u vrijeme kada je objavio prvo izdanje svojeg djela. Jedno drugo njegovo djelo, Synopsis Aristotelis Metaphysices ad normam christianae religionis explicatae, emendatae et completae (1596.), imalo je više odjeka tek kasnije, u prvoj polovici 18. stoljeća.

\subsection{Rudolf Göckel}

U obnovi metafizike na protestantskim sveučilištima posebno je bio uspješan i utjecajan kalvinistički uomo universale Rudolf Göckel, poznatiji pod latinskim imenom Rodolphus Goclenius (1547.-1628.), sa svojim uvodom u metafiziku Isagoge in peripateticorum et scholasticorum primam philosophiam, quae dici consuevit metaphysica (1598.). Mnogi povjesničari filozofije u tom djelu vide početak

10 U ovom radu, koji je dio većeg projekta, izraz protestantska skolastika rabim prije svega u smislu filozofije koja se podučavala na protestantskim sveučilištima poslije smrti Melanchthona (1560.) do 1750. godine. U to dijelom uključujem i samog Melanchthona jer smatram očitim da je svojim djelima utjecao na obnovu aristotelizma na protestantskim sveučilištima. Prema Maxu Wundtu u istom značenju koristim izraz Schulmetaphysik. Nastao je po uzoru na Christiana Wolffa i Immanuela Kanta, kod kojih se izrazi Metaphysik i metaphysisch odnose na cijelu filozofiju, dakle uključuju etiku i političku filozofiju. 
ozbiljne obnove metafizike u protestantskim krajevima. To je djelo rezultat intenzivnog bavljenja filozofijom Beneta Perera i Pedra Fonsece nakon Göckelova angažmana u Marburgu. ${ }^{11}$ Zamišljeno je kao uvod u metafiziku, ali je u stvari uglavnom leksikon filozofskih pojmova, uz mnoštvo dijagramskih prikaza. U predgovoru ističe da je prva filozofija »scientia universalis, quae explicat de universalissimis, hoc est quae sparsa sunt per omnes scientias « (Göckel, 1598, 8). ${ }^{12}$ Od prve filozofije razlikuje metafiziku koja se kao scientia particularis bavi partikularnim metafizičkim predmetima kao što je Bog. Može se reći kako je tu riječ o podjeli na opću i specijalnu metafiziku. Ali ni Max Wundt ni Ernst Vollrath nisu u pravu kada u tom predgovoru nalaze prvi i najvažniji izvor razlikovanja opće i specijalne metafizike (Wundt, 1939, 58; Vollrath, 1962, 265). Već je ranije španjolski isusovac Benit Perera (1535.-1610.) oko 1562. uveo tu razliku (Rompe, 1968, 7-13). ${ }^{13}$ Međutim, nema dvojbe da je Göckel zaista razlikovao opću i specijalnu metafiziku. To je očito već iz prvih Göckelova objašnjenja o naravi metafizike: »Primae philosophiae, quam vulgo metaphysicam vocant, quidem duas partes faciunt. Unam universalem de ente in communi; alteram particularem, de Deo, daemonibus \& intellectu separato a corpore «(Göckel, 1598, 126).${ }^{14}$ Dodaje da je takvog karaktera Aristotelova prva filozofija. No već je u idućem odlomku jasno da Göckel, vjerojatno i za razliku od Aristotela, prvu filozofiju veže uz onu filozofiju koja se bavi bićem općenito, dakle ono što je kasnije bila opća metafizika ili ontologija. ${ }^{15}$ Partikularnu filozofsku znanost, kasniju specijalnu metafiziku, razlikuje prema predmetu istraživanja: dio koji se bavi Bogom je transnaturalis, a dio koji se bavi prirodnim stvarima je naturalis (Göckel, 1598, 127). ${ }^{16}$ Važno je što Göckelova podjela na univerzalnu i partikularnu znanost odražava spoznajnu podjelu. To je dosta važno jer time započinje jedan kompromis u protestantskoj Schulmetaphysik, koji se proteže do Wolffa i Kanta, naime da se opća metafizika shvaća kao znanje o biću kao biću (dakle dijelom nasuprot Suárezovu ens qua ens reale), ali istovremeno i kao temelj spoznajnog razlikovanja metafizičkih bića (za razliku od Timplerova čistog ens qua cognoscibile).

11 Predavao je u Marburgu od 1581. do 1627. (Lamanna, 2009). Sveučilište u Marburgu u Göckelovo vrijeme bilo je važno središte kalvinističke teologije i znanosti.

12 „Prva filozofija univerzalna je znanost koja objašnjava najopćenitije stvari koje su raspršene po svim znanostima." Citate iz izvora na stranim jezicima preveo je autor članka.

13 Podsjećam na to da je Albert Zimmermann uvjerljivo dokazao da se eksplicitna razlika treba tražiti u visokoj skolastici $(1966 ; 1998)$.

14 „Postoje naime dva dijela prve filozofije koju obično nazivamo metafizikom. Jedan je univerzalan i bavi se bićem općenito; drugi je partikularan i bavi se Bogom, duhovnim bićima i intelektom odvojenim od tijela."

15 Christian Wolff dosljedno se drži takva shvaćanja, što je vidljivo iz naslova njegova djela o općoj metafizici: Philosophia prima seu ontologia. No kod Descartesa, Wolffa i Kanta ipak prevladava shvaćanje da je metafizika obuhvatni pojam, istoznačan s pojmom filozofije, a u njoj se ističe fundamentalan dio koji se naziva prva filozofija (Descartes), ontologija (Wolff) ili transcendentalna filozofija (Kant).

16 Lohr je zaključio da Göckel opću metafiziku izjednačava s prvom filozofijom, a specijalnu s metafizikom $(1999,291)$. 
Göckelovo kasnije djelo Lexicon philosophicum (1613.) definitivno je utvrdilo njegov status najvećeg znanstvenog autoriteta svojeg doba. Utjecaj tog djela trajao je gotovo stotinjak godina. ${ }^{17}$ Isto tako njegovo sljedeće djelo pod naslovom Lexicon philosophicum Graecum (1615.), didaktički osmišljeno, bilo je korisno generacijama studenata i utjecalo je na oblikovanje filozofijske terminologije na njemačkom jeziku.

\subsection{Jakob Martini}

Posebne zasluge za otvaranje luteranske sredine prema skolastičkoj tradiciji, osobito isusovačkoj metafizici, imao je Jakob Martini (1570.-1649.), od 1602. profesor logike i metafizike, kasnije etike i teologije, u Wittenbergu. U njegovu djelu Theorematum metaphysicorum exercitationes (1603.) vidljiv je jak utjecaj Giacoma Zabarelle, ali i blagonaklona recepcija isusovačke metafizike. O tim se tezama raspravljalo te godine u Wittenbergu, na Lutherovu i Melanchthonovu sveučilištu. Karl Eschweiler naziva je, blagom ironijom, „wittenberška metafizika“ (Wittenberger Metaphysik) (Eschweiler, 1928, 29). Raspored i prezentacija teza otkriva porijeklo iz Suárezova priručnika, iako Martini to posebno ne ističe. No već u drugoj vježbi (Exercitatio secunda) Martini spominje Suárezovo ime: »hinc Suarez tale ponit discrimen inter conceptum formalem et obiectivum « (Martini, 1603a, theorema 9.4) ${ }^{18}$ Na nekim mjestima eksplicitno navodi Suárezove riječi, iako u tekstu ne označuje gdje se to nalazi u njegovu djelu. ${ }^{19}$ Pitanje univerzalija obrađeno je u Suárezovu duhu i odražava njegov osebujni nominalizam, primjerice: »Unde colligitur [...] unitatem universalem non esse ante mentis operationem neque in rebus ipsis invenire, sed per intellectus functionem insurgere, sumpto fundamento sive occasione ex ipsis singularibus« (Martini, 1603b, theorema 9.18-25). ${ }^{20}$ Martini je također bio važan u organizaciji luteranske crkve. Budući da je bio autor niza udžbenika iz logike i ostalih filozofskih disciplina, njegovim je akademskim i utjecajem i djelovanjem preko crkvenih funkcija došlo do zamjene starih Melanchthonovih udžbenika dijalektike i retorike na luteranskim gimnazijama i sveučilištima. Novi su udžbenici bili otvoreni za metafiziku i skolastičku tradiciju. ${ }^{21}$

17 Važno je također što u tom djelu tvrdi kako philosophia prima koristi model apstrakcije po uzoru na matematiku (Göckel, 1613, 16). Poznato je da je Christian Wolff prihvatio i sustavno primijenio taj stav.

18 „Ovdje Suárez postavlja takvo razlučivanje formalnoga i objektivnoga pojma.“

19 Primjerice: »secunda ratio eleganter ponitur a Suarez his verbis« (Martini, 1603a, theorema 9.8).

20 „Na temelju toga se zaključuje [...] da univerzalno jedinstvo ne postoji prije umske radnje niti se nalazi u samim stvarima, nego nastaje djelovanjem intelekta, pod pretpostavkom temelja ili povoda iz samih pojedinačnih stvari.“ Naravno, time Suáreza ne ubrajam u nominaliste, nego tvrdim da u njegovoj epistemologiji nalazimo elemente nominalizma, što ima za posljedicu da je njegov metafizički realizam indirektan.

21 Jasne tragove recepcije Suárezove metafizike u luteranskoj sredini nalazimo kod luterana Henninga Arnisaeusa (1570.-1636.), profesora moralne filozofije u Frankfurtu na Odri, a kasnije medicine u Helmstedtu, u njegovu djelu De constitutione et partibus metaphysicae tractatus (1606.). 


\subsection{Clemens Timpler}

Kao jedan od najvećih autoriteta in metaphysicis cjelokupnoj se protestantskoj sredini nametnuo njemački kalvinist Clemens Timpler (1563.-1624.), najoriginalniji protestantski filozof tog doba, nakon što je objavio svoje djelo Metaphysicae systema methodicum (1604.). ${ }^{22}$ Može se reći da je njegov utjecaj također mjerljiv i jakom luteranskom opozicijom protiv njegove filozofije. Timplerovi sljedbenici bili su naravno kalvinisti već spomenuti Jakob Lorhard ${ }^{23}$ te Matthias Martinus (1572.-1630.). Na luteranskoj strani bilo je dosta protivnika, primjerice ranije spomenuti Hennig Arnisaeus i Jakob Martini, te nekoliko mlađih kao Christoph Scheibler (1589.-1653.), Johann Scharff (1595.-1660.) i Abraham Calov (1612.1686.). Neki su, primjerice Martini i Scheibler, u jasnoj opoziciji spram Timplera prihvaćali Suárezaovu formulu ens reale kao određenje predmeta metafizike (Devaux i Lamanna, 2009, 177).

Za razliku od većine svojih prethodnika, koji su samo htjeli prezentirati „čistog“ Aristotela, Timpler neopterećeno navodi neke suvremenike, primjerice Zabarellu, Fonsecu i Suáreza. Ono što je postalo vrlo važno u tradiciji njemačke protestantske metafizike način je kako u svojem djelu određuje predmet metafizike. Metafiziku definira na sljedeći način: »metaphysica est ars contemplativa, quae tractat de omni intelligibili, quatenus ab homine naturali rationis lumine sine ullo materiae conceptu est intelligibile« (Timpler 1608, 1). ${ }^{24}$

Očito je da metafiziku shvaća epistemološki. Njezina je zadaća promišljati „naravnim svjetlom“, tj. intelektualnom intuicijom, sve što je mislivo, ali neovisno o materiji, odnosno kontekstu u kojem je ostvareno, dakle sve što je mislivo kao mislivo. Na samom početku svojeg djela, u petom problemu prvog poglavlja prve knjige, Timpler raspravlja o tome što je svojstven i primjeren objekt metafizike (proprium et adaequatum subiectum metaphysicae) (Timpler 1608, 6-7). Odbacuje formulu iz aristotelovske tradicije da je metafizika znanost o biću kao biću (scientia entis quatenus ens) jer takav pristup nije adaequatus toti metaphysicae, koja se ne bavi samo bićem kao bićem nego i bićem ako je supstancija ili akcident, pa je zato prema Timplerovu mišljenju formula „biće kao biće“ ne-

22 Prvo izdanje tiskano je u Steinfurtu 1604. godine. Nova izdanja: Lich 1604., Hanau 1606., 1608., 1612. i 1616., Frankfurt na Majni 1607. i 1612., Marburg 1607. (Freedman, 2009, 3). Hanavsko izdanje iz 1608. s bilješkama Rudolfa Göckela (notae et scholia in singula capita, nunc denuo ab auctore recognita, također u kasnijim izdanjima) Timpler je smatrao definitivnim, što je vidljivo i na samoj naslovnici, iako Göckel u tim primjedbama iznosi neslaganje s nekim Timplerovim tezama. Struktura definitivnog teksta je sljedeća: Timplerova Epistola dedicatoria ( 7 str.); Göckelova Praefatio ad lectorem (5 str.); Timplerova Praefatio auctoris ad lectorem de nova hac editione (2 str.); Clementis Timpleri Technologia seu tractatus generalis de natura \& differentiis artium liberalium (str. 1-40); Timplerov glavni tekst Metaphysicae libri quinque (str. 1-581); Index librorum, capitum et problematum Metaphysicae (52 str.); Rodolphi Goclenii in M. Clementis Timpleri Metaphysicam praefatio (str. 1-7); Rodolphi Goclenii in M. Clementis Timpleri Metaphysicam notae et scholia (str. 8-127).

23 Vidi bilj. 1.

24 „Metafizika je kontemplativno umijeće koje obrađuje sve inteligibilno ako je naravnim svjetlom uma inteligibilno bez ikakva shvaćanja materije.“ 
dovoljno općenita. ${ }^{25}$ Njegov je prijedlog da se rabi širi pojam koji obuhvaća sve mislivo: »Nos latius extendimus rem in metaphysica consideratam ut sub ea $\pi \tilde{\alpha} v$ voๆtóv, hoc est omne intelligibile comprehenduntur «(Timpler 1608, 7). ${ }^{26}$

Sve mislivo je ili nešto (aliquid) ${ }^{27}$ ili ništa (nihil). Kao mislivo „nešto“ je za Timplera ekvivalentno biću, ${ }^{28}$ pa se biće prije svega shvaća kao nešto mislivo. Ta su dva fundamentalna pojma — aliquid i nihil — prema njegovu shvaćanju kontradiktorna u odnosu jedan spram drugoga, a načelo proturječnosti je nedokazivo i apsolutno nužno. Shvaćanje da se metafizika bavi onim što je mislivo, odnosno inteligibilno, bilo je u daljnjem razvoju protestantske metafizike važna razlika spram Suárezova shvaćanja metafizike jer Suárez ostaje kod svoje definicije da je predmet metafizike ens qua ens reale: »diximus obiectum adaequatum et directum metaphysicae non esse ens commune ad reale et rationis, sed ad reale tantum « (DM 47.3.3; vol. 26, 794). ${ }^{29}$

Suárez je također smatrao i da ens rationis na neki način spada u područje metafizike, ali ga nije smatrao istinskim bićem jer nije po sebi mislivo: »cum entia rationis non sint vera entia, sed quasi umbrae entium, non sunt per se intelligibilia, sed per aliquam analogiam et conjunctionem ad vera entia, et ideo nec etiam sunt per se scibilia « (DM 54.0.1; vol. 26, 1015). ${ }^{30}$ Timpler predmet metafizike shvaća kao ens ut universalissimum koje per se obuhvaća ens reale i ens rationis jer je oboje mislivo kao takvo. No Timpler taj stav nije ni sustavno obrazložio niti ga je koristio u kontekstu ostalih metafizičkih objašnjenja, iako je stav da je predmet metafizike mislivo kao mislivo imao dalekosežne posljedice za shvaćanje opće metafizike ili ontologije u protestantskoj skolastici. Osim toga, Timpler također transcendentalne pojmove drugačije tretira od Suáreza, naime odvaja unum od drugih dvaju pojmova, verum i bonum, koji su konvertiblini s pojmom ens. Kasniji protestantski metafizičari prihvatili su pod utjecajem Suáreza sva tri pojma, primjerice Johannes Stier (1599.-1648.) u djelu Praecepta metaphysicae (1641.). ${ }^{31}$

25 Za podršku svojemu shvaćanju poziva se na Fonsecin komentar Aristotelove Metafizike (Fonseca, 1577-1589, 1.1.1.2). Naravno Fonseca na tom mjestu, pa ni nigdje drugdje, ne može dati podršku Timpleru. Neupitna je konstanta katoličkih filozofa da metafiziku shvaćaju kao znanost o biću kao biću.

26 „Mi proširujemo problem razmatran u metafizici tako da se pod njim shvaća sve misaono, tj. sve inteligibilno." U istom kontekstu kaže: »concludo subiectum proprium et adaequatum metaphysicae esse omne intelligibile« (Timpler, 1608, 8), tj. „zaključujem da je svojstveni i primjereni predmet metafizike sve inteligibilno“.

27 Timpler kaže aliquid aut est, što upućuje na već spomenutu ekvivalentnost nečega i bića, onoga što je mislivo i onoga što jest.

28 Za takvo shvaćanje pojma nešto Timpler se (neopravdano) poziva na isusovca Pedra da Fonseca (Devaux i Lamanna, 2009, 178).

29 „Rekli smo da primjereni i izravni objekt metafizike nije zajedničko biće u odnosu na realno i umsko biće, nego samo ono što je zajedničko u odnosu na realno biće.“

30 „Budući da umska bića nisu istinska bića, nego kao neke sjene bića, nisu inteligibilna po sebi, nego po nekoj analogiji i povezivanju s istinskim bićima, pa zato nisu ni znana po sebi.“

31 Djelo je, poput Lorhardova, pod jakim utjecajem ramističke tradicije diagramatskog prikaza znanosti. Za Suáreza kaže: »communis omnium metaphysicorum doctor et magister« (Stier, 1641, 3). 
Timplerova je velika zasluga to da je detaljno objasnio gotovo sve ključne metafizičke termine iz aristotelovske tradicije te time pobudio velik interes za metafiziku na protestantskim sveučilištima. No ponajviše je u humanističkom duhu, dakle u Melanchthonovoj tradiciji, oštroumno objašnjavao ključne termine. Nedostajalo je dakle sustavno povezivanje pojmova. Očito je upravo taj nedostatak sustavnog shvaćanja metafizike, pa prema tomu i veće upotrebljivosti u teološkim raspravama, donio Suárez sa svojim Metafizičkim disputacijama, na njemačkom području tiskom dostupno od 1600. godine, djelom koje je pisano jasno i suvislo, a cijeli je sadržaj sustavno i pregledno prezentiran. Globalni uspjeh Suárezova priručnika leži ne samo u sustavnoj doktrini, nego i u didaktički osmišljenoj prezentaciji. ${ }^{32}$

Najpoznatiji Timplerov sljedbenik i oponašatelj bio je već spomenuti tvorac neologizma ontologija, kalvinist Jacob Lorhard. Njegovo djelo Ogdoas scholastica (1606.), u kojem se prvi put pojavljuje termin ontologija, nema pretenzije na originalnost. Glavni mu je cilj, u duhu ramističke tradicije, dijagramatski prikazati sadržaj Timplerova metafizičkog udžbenika tako da bude što više razumljiv studentima. Cijelo se djelo sastoji uglavnom od podjela ključnih stručnih pojmova iz osam filozofskih područja koja se spominju u punom naslovu djela, a u toj podjeli prevladava dihotomska podjela poznata iz Platonova Sofista. Inače je u prvim desetljećima 17. stoljeća Timplerovo djelo Metaphysicae systema methodicum (1608.) bilo najraširenije djelo po kalvinističkim gimnazijama, akademijama i sveučilištima. U duhu Timplerove metafizike Lorhard određuje predmet metafizike kao najopćenitiji pojam pomislivosti. U dijagrafu metafizike ili ontologije (Metaphysices seu ontologiae diagraphe) definira metafiziku, koristeći miješano grčke i latinske termine, na gotovo istovjetan način kao Timpler:

\begin{tabular}{|c|c|}
\hline Timpler (1604.) & Lorhard (1606.) \\
\hline $\begin{array}{l}\text { metaphysica est ars contemplativa, } \\
\text { quae tractat de omni intelligibili, } \\
\text { quatenus ab homine naturali rationis } \\
\text { lumine sine ullo materiae conceptu est } \\
\text { intelligibile «33 }\end{array}$ & 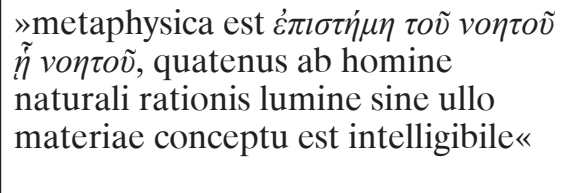 \\
\hline
\end{tabular}

Dakle Lorhard mijenja samo početak definicije, pa umjesto latinskih riječi ars contemplativa, quae tractat de omni intelligibili stavlja grčku formulu po uzoru na

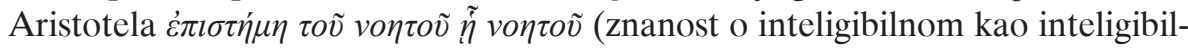
nom, odnosno o mislivom kao mislivom).

32 Marco Lamanna (2014) analizira razlike između Göckela i Timplera te s pravom zaključuje kako je Göckel puno bliži Suárezu, napose u načinu kako tumači sinonimnost izraza ens, aliquid i res.

33 Definicija metafizike u izdanjima iz 1604. i 1608. potpuno je istovjetna. 


\subsection{Christoph Scheibler}

Na luterana Jakoba Martinija i kalvinista Clemensa Timplera nastavlja se dvosveščana rasprava Opus metaphysicum (1617.) mladoga, tada 28-godišnjeg Christopha Scheiblera (1589.-1653.), ${ }^{34}$ koji metafiziku shvaća kao čisto učenje o bitku, a nasuprot starijoj generaciji reformatora pojmove Bog, anđeo i duša tretira kao predmete metafizike, a ne isključivo teologije. No podjelu bića na ta tri metafizička predmeta obrazlaže epistemološki. Postoji suglasnost da je Scheiblerovo djelo bio najutjecajniji i najrašireniji priručnik metafizike na protestantskim sveučilištima. Također se može reći da je to djelo u najvećoj mjeri doprinijelo Suárezovoj popularnosti među protestantima. Raspored obrađenih tema, posebno u drugom svesku, u velikoj mjeri ovisi o Suárezovim Metafizičkim disputacijama. Znamo da je Suárez svoju raspravu de entibus rationis stavio na sam kraj svojeg djela. Scheibler postupa sustavnije i tu raspravu stavlja na konac općenitijeg dijela svojeg djela. Također, u skladu s njemačkom tradicijom, o anđelima raspravlja odmah poslije rasprave o Bogu, a Suárezova rasprava o tome raspršena je na više disputacija. Ugled i utjecaj Scheiblerova djela bio je iznimno velik, pa su ga neki kasniji teolozi, primjerice Jacob Friedrich Reimmann (1668.1743.), označavali kao „protestantskog Suáreza“ (Petersen, 1921, 290). Jedan od najuglednijih kalvina u Nizozemskoj teolog Gisbert Voetius (Gijsbert Voet, 1589.-1676.) preporučuje svojim studentima Scheiblera i Suáreza (Eschweiler, 1928, 26).

\subsection{Petri Burgersdijk i Jacobus Revius}

Filozofski autoritet Francisca Suáreza bio je također velik u Nizozemskoj. Vidljiv je u nekim utjecajnim djelima kalvinskih profesora. Navest ću samo dva poznata. Leidenski filozof Franco Petri Burgersdijk (1590.-1635.) napisao je posthumno objavljeno djelo Institutiones metaphysicae (1640.). Riječ je zapravo o praktičnom sažetku glavnih misli Suárezova metafizičkog djela. Naravno kalvinski je profesor pazio da njegov prikaz grijeha i slobode bude drugačiji od Suárezova. Drugo je djelo još neobičnije, a bilo je i raširenije među nizozemskim studentima. Autor je kalvinistički teolog Jacobus Revius (1586-1658), a naslov djela je Suarez repurgatus, sive syllabus Disputationum metaphysicarum Francisci Suarez cum notis (1644.). Revius objašnjava da je pribjegao dodavanju bilježaka koje pročišćavaju Suárezov tekst jer su se uz dobre njegove misli u kalvinsku teologiju uvukle i loše na koje treba upozoriti. Njegovo je djelo u manjoj mjeri kalvinska cenzura prihvatljivih stavova, a u većoj mjeri borba za istinsko razumijevanje Suárezove metafizike. ${ }^{35}$

34 Prvi svezak broji 880 str., a drugi 799. Prvo je izdanje 1617. tiskao u Gießenu, potom slijede dva nova izdanja 1622. i 1629. te pretisci 1636. i 1657. godine. Jedno je izdanje tiskano u Oxfordu 1633. godine.

35 Suárezov utjecaj na kasniju luteransku i kalvinističku teologiju obrađuje John Kronen (2015). 


\subsection{Osporavanje Descartesovoj i otvaranje skolastičko-aristotelovskoj metafizici}

Utjecaj nove Descartesove filozofije na njemačku protestantsku skolastiku uslijedio je nakon što se Suárezova metafizika prilično ukorijenila, a dolazio je preko Nizozemske. Osporavanje kartezijanske filozofije na nizozemskim sveučilištima bilo je povezano s vrednovanjem skolastičke filozofije za potrebe kalvinske teologije, a time se obično izražavao i stav prema novoj isusovačkoj metafizici. Primjerice oko 1650. bio je vrhunac spora koji su vodili kalvinski teolog Gisbertus Voetius (Gijsbert Voet; 1589.-1676.) i kartezijanac Henricus Regius (1598.-1679.). Kažemo „kartezijanac“ jer je bio blizak Descartesu i vodio je prepisku s njim, ali ispravnije bi bilo reći da je Regius tražio neovisno stajalište između Descartesa i Suáreza. Senat grada Utrechta i kuratorij sveučilišta prekinuo je spor između Voetiusa i Regiusa preporukom da se zadrži skolastičko-aristotelovska filozofija, a time i nova isusovačka metafizika. Isto tako, kuratorij Sveučilišta u Leidenu odlučio je 1651. godine da treba prestati svađa oko Descartesove filozofije i da se profesori trebaju držati uobičajene aristotelovske filozofije, što zapravo znači one aristotelovske filozofije koja je tada prevladavala, a to je bila isusovačka škola (Bohatec, 1912, 34 i 155). U Nizozemskoj u prvoj polovici 17. stoljeća kalvinska, odnosno reformirana teologija, za razliku od ondašnje luteranske, posebno je cijenila upotrebu naravnoga svjetla uma (lumen rationis naturale) kako su je prakticirali isusovački filozofi.

Rani Suárezov utjecaj u Njemačkoj u najvećoj je mjeri vezan za njegovo metafizičko djelo. No dodatni je utjecaj išao i preko isusovaca koji su bili aktivni na različitim sveučilištima. Do konca 16. stoljeća isusovci su bili zastupljeni na svim katoličkim sveučilištima (Ingolstadt, Beč, Würzburg, Mainz, Trier), u Pragu, Kölnu i Freiburgu su u početku paralelno imali svoje kolegije. Od 1625. do ukinuća reda 1773. isusovci su bili nositelji filozofskih i skolastičko-teoloških katedri na svim katoličkim sveučilištima u njemačkim zemljama. Jedina je iznimka bilo benediktinsko sveučilište u Salzburgu, koje je u 17. stoljeću ostalo vjerno starijem tomizmu i nije prihvaćalo isusovačke inovacije (Duhr, 1913, 541-595). Zanimljive su okolnosti osnivanja sveučilišta u Dillingenu. Početna je ideja bila da dominikanac Petrus de Soto (1493.-1563.), poznati teolog s koncila u Trientu, utemelji novo katoličko sveučilište. Delegirani dominikanci s drugih sveučilišta, primjerice Louvaina i iz Španjolske, nisu uspjeli oživiti ideju jer ili su umrli na putu ili ubrzo nakon dolaska. Sam Petrus de Soto morao je preuzeti novu dužnost, pa je cijela inicijativa prepuštena isusovcima koji su koncem 1663. preuzeli vođenje sveučilišta (Specht, 1902, 10; 56). Uspješno su ga vodili do ukinuća reda. Ruđer Bošković je na svojem povratku iz Engleske vjerojatno kratko boravio u Dillingenu i moguće je da je doprinio osnivanju ondašnje zvjezdarnice. ${ }^{36}$

36 Ruđer Bošković na povratku iz Engleske 4. travnja 1761. boravio je u Augsburgu (Marković, 1968-1969, 606). Ondje je ostao do 6. travnja i moguće je da je boravio i u Dillingenu, što bi se očekivalo od jednog isusovca. Naime, nekoliko godina poslije njegova proputovanja izgrađena je zvjezdarnica, a znamo kako je Bošković, jedan od najuglednijih astronoma svojeg doba, često bio savjetnik za tehnička pitanja u astronomiji, od mjernih instrumenata do nacrta zvjezdarnica. 
Razvojne faze protestantske skolastike izgledale bi ovako:

1517.-1560. Melanchthonov filozofski utjecaj, posebno preko njegova djela

Erotemata dialectices (više izdanja i prerada od 1520.);

1560.-1600. uvođenje metafizičkih tema, intenzivnije bavljenje Aristotelovom

Metafizikom;

1600.-1650. utjecaj Francisca Suáreza;

1650.-1700. intenzivan kartezijanski utjecaj;

1700.-1750. jak Leibnizov utjecaj i dominacija Christiana Wolffa.

\section{Zaključak}

Na koncu možemo još jednom pokušati sažeti razloge tako velike popularnosti Suárezove metafizike u protestantskoj sredini. Ta recepcija sigurno nije bila mehaničko preuzimanje. Sretnim stjecajem okolnosti nova je metafizika odgovarala potrebi protestantske teologije da dobije zadovoljavajuce odgovore na sve očitije spekulativne potrebe. Nije naišla na velike negativne reakcije jer u prvoj fazi recepcija nije bila direktno vezana za protestantsku dogmatiku. Od početka isusovačka metafizika nije shvaćena kao spekulacija koja se isključivo bavi transcendentnim pitanjima o Bogu. Uglavnom je prikazivana kao shematski ontologizam koji svako biće opisuje pod vidom jednostavnosti i složenosti, prema afekcijama bića te nudi potrebne kategorije za spoznaju svake stvari. Shvaćena je kao fundamentalna, odnosno opća znanost koja u sebi sadržava pretpostavke drugih oblika znanja. Na neki je način neutralna spram temeljnih teoloških pitanja jer ništa ne prejudicira. Prva generacija reformatora bila je pod utjecajem talijanske renesanse, posebno Giacoba Zabarelle, a primarni joj je interes bila dijalektika, odnosno logika. Mlađi reformatori bili su obrazovani u toj tradiciji. Praktični intelektualizam unutrašnja je srodnost Zabarelle i Suáreza. To je također važan razlog za brzo prihvaćanje isusovačke metafizike.

\section{Literatura:}

Alsted, Johannes Heinrich (1613). Metaphysica tribus libris tractata. Herborn.

Arnisaeus, Hennig (1606). De constitutione et partibus metaphysicae tractatus. Frankfurt na Odri: J. Thimen.

Bohatec, Josef (1912). Die cartesianische Scholastik in der Philosophie und reformierten Dogmatik des 17. Jahrhunderts: I. Teil. Leipzig: A. Deichert.

Cramer, Daniel (1594). Isagoge in Metaphysicam Aristotelis, quaestionibus rotunde et dilucide comprehensa; in usum et gratiam tyronum qui ad lympidos ipsius philosophi fontes primum contendut. Hannover: W. Antonius.

Devaux, Michaël; Lamanna, Marco (2009). The rise and early history of the term ontology (1606-1730). Quaestio, 9, 173-208.

$\mathrm{DM}=$ Francisco Suárez, Disputationes Metaphysicae universam doctrinam duodecim librorum Aristotelis comprehendentes. U: Carolo Berton (prir.), R. P. Francisci Suarez e Societate Jesu Opera Omnia. Vol. 25 i 26. Pariz: Vivès, 1861. SUnutartekstna uputnica sadržava kraticu DM, broj disputacije, broj poglavlja i broj odlomka te broj knjige i stranicu, npr.: DM 8.3.18; vol. 25, 288.Ć 
Duhr, Bernhard (1913). Geschichte der Jesuiten in den Ländern deutscher Zunge: Band 1: Teil 1. Freiburg im Breisgau: Herder.

Elswich, Johannes Hermann von (1720). Ioannis Lavnoii, theologi Parisiensis De varia Aristotelis in Academia Parisiensi fortuna et Ioannis Ionsii Holsati De historia Peripatetica dissertatio, edidit et De varia Aristotelis in scholis protestantium fortuna schedisma praemisit, adiecto indice necessario. Wittenberg: Samuel Hannaver.

Eschweiler, Karl (1928). Die Philosophie der spanischen Spätscholastik auf den deutschen Universitäten des 17. Jhs. Münster: Aschendorff (Spanische Forschungen der GörresGesellschaft).

Fonseca, Pedro da (Fonseca, Petrus) (1577-1589). Commentariorum in libros Metaphysicorum Aristotelis tomi IV. Rim.

Freedman, Joseph S. (1988). European academic philosophy in the late sixteenth and early seventeenth centuries: The life, significance, and philosophy of Clemens Timpler (1563/4-1624). 2 volumes. Hildesheim: Georg Olms.

Freedman, Joseph S. (2009). The godfather of ontology? Clemens Timpler, »All that is intelligible«, academic disciplines during the late 16th and early 17th centuries, and some possible ramifications for the use of ontology in our time. Quaestio, 9, 3-40.

Gaß, Wilhelm (1854). Geschichte der protestantischen Dogmatik in ihrem Zusammenhange mit der Theologie: Band 1. Berlin: Georg Reimer.

Göckel, Rudolf (1598). Isagoge in peripateticorum et scholasticorum primam philosophiam, quae dici consuevit metaphysica: Accesserunt disputationes huius generis aliquot. Frankfurt: M. Z. Palthen.

Göckel, Rudolf (1613). Lexicon philosophicum, quo tanquam clave philosopphiae fores aperiuntur. Frankfurt: M. Becker.

Göckel, Rudolf (1615). Lexicon philosophicum Graecum, opus sane omnibus philosophiae alumnis valde necessarium cum perspicientia. Marburg: P. Muscyl.

Jasper, Joseph (1898). Leibniz und die Scholastik (Diss. Leipzig). Münster: Coppenrath.

Kronen, John (2015). Suárez's influence on protestant scholasticism — the cases of Hollaz and Turretin. U: Victor M. Salas i Robert L. Fastiggi (ur.), A Companion to Francisco Suárez (str. 221-247). Leiden — Boston: Brill.

Lamanna, Marco (2008). La nascita dell'ontologia: L'opera metafisica di Rudolph Göckel (1547-1628). Diss. Bari.

Lamanna, Marco (2009). De eo enim metaphysicus agit logice: Un confronto tra Pererius e Goclenius. Medioevo: Rivista di stroria della filosofia medievale, 34, 315-360.

Lamanna, Marco (2014). Ontology between Goclenius and Suárez. U: Lukáš Novák (ur.), Suárez's Metaphysics and its Historical and Systematic Context (str. 135-151). Berlin: de Gruyter.

Leibniz, Gottfried Wilhelm (1875). Die philosophischen Schriften, herausgegeben von C. I. Gerhardt: Band 1. Berlin: Weidmann.

Leinsle, U. G. (1985). Das Ding und die Methode: Methodische Konstitution und Gegenstand der frühen protestantischen Metaphysik. Augsburg: Maro.

Lewalter, E. (1967). Spanisch-jesuitische und deutsch-lutherische Metaphysik des 17. Jahrhunderts: 2. Auflage. Darmastadt: Wissenschaftliche Buchgesellschaft.

Lohr, Charles H. (1999). Metaphysics and natural philosophy as sciences: The Catholic and the Protestant views in the sixteenth and seventeenth centuries. U: Constance Blackwell i Sachiko Kusukawa (ur.), Philosophy in the Sixteenth and Seventeenth centuries: Conversations with Aristotle (str. 280-295). Aldershot: Ashgate.

Lorhard, Jacob (1606). Ogdoas scholastica, continens diagraphen typicam artium: Grammatices (Latinae, Graecae), Logices, Rhetorices, Astronomices, Ethices, Physices, Me- 
taphysices, seu Ontologiae; ex praestantium huius temporis virorum lucubrationibus, pro doctrinae \& virtutum studiosa juventute confecta. St. Gallen: G. Straub.

Lorhard, Jacob (1613). Theatrum philosophicum in quo artium et disciplinarum philosphicarum plerarumque omnium Grammatices Latinae, Graecae, et Hebraae, Logices, Rhetorices, Arithmetices, Geometriae, Musices, Astronomices, Ethices, Physices, Metaphysices praecepta in perpetuis schematismis ac typis tanquam in speculo cognoscendo objiciuntur. Basel: K. Waldkirch.

Marković, Željko (1968-1969). Ruđe Bošković. 2 sveska. Zagreb: Jugoslavenska akademija znanosti i umjetnosti.

Martini, Jakob (1603). Theorematum metaphysicorum exercitationes quatuordecim, continentes universam metaphysicam in formam scientiae compendiosae redactam. Wittenberg: Schurer.

Öchslin, Nikaolaus (1573). Philosophiae triumphus, hoc est metaphysica philosophandi methodus, qua divinitus inditis menti notitiis humanae rationes eo deducuntur ut firmissimis inde constructis demonstrationibus aperte rei veritas elucescat. Basel: S. Henricpetri.

Öchslin, Nikaolaus (1596). Synopsis Aristotelis Metaphysices ad normam christianae religionis explicatae, emendatae et completae. Hanau: Adam Schmid.

Pereira, José (2006). Suárez: Between scholasticism and modernity. Milwaukee: Marquette University Press.

Petersen, Peter (1921). Geschichte der aristotelischen Philosophie im protestantischen Deutschland. Leipzig: Felix Meiner.

Stier Johann (1641). Praecepta metaphysicae, ex probatis auctoribus collecta \& iuvandae memoriae causa tabulis synopticis inclusa: Editio secunda correctior. Jena: J. Birckner.

Rintelen, Fritz (1903). Leibnizens Beziehungen zur Scholastik. Archiv für Geschichte der Philosophie, 16, 157-188.

Rompe, Elisabeth Maria (1968). Die Trennung von Ontologie und Metaphysik: Der Ablösungsprozess und seine Motivierung bei Benedictus Pererius und anderen Denkern des 16. und 17. Jahrhunderts. Bonn: Universitätsdruck.

Specht, Thomas (1902). Geschichte der ehemaligen Universität Dillingen. Freiburg im Breisgau: Herder.

Stier, Johann (1641). Praecepta metaphysicae, ex probatis auctoribus collecta \& iuvandae memoriae causa tabulis synopticis inclusa: Editio secunda corrrectior. Jena: J. Birckner.

Timpler, Clemens (1604). Metaphysicae systema methodicum libri quinque, in quo non tantum praecepta de rebus ad hanc disciplinam pertinentibus breviter et perspicue traduntur, sed etiam ad confirmanda et illustranda praecepta, quaestiones controversiae in utramque partem disputantur et deciduntur. Hanau: Antonius.

Timpler, Clemens (1608). Metaphysicae systema methodicum, libris quinque per theoremata

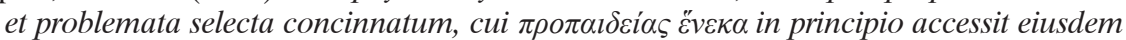
Technologia, hoc est tractatus generalis et utilissimus de natura \& differentiis artium liberalium, cum Praefatione auctoris ad lectorem, qua omnes alias editiones pro spuriis \& adulterinis habet, ubicunque locorum fuerint impressae. Seorsum accesserunt Rodolphi Goclenii philosophi cl. notae \& scholia in singula capita, nunc denuo ab auctore recognita. Hanau: Antonius.

Tröltsch, Ernst (1891). Vernunft und Offenbarung bei Joh: Gerhard und Melanchthon. Göttingen: E. A. Huth.

Vlačić, Matija (1994). Paralipomena dialectices. Preveli i priredili Josip Talanga i Filip Grgić. Zagreb: Skolska knjiga.

Vleeschauwer, H. J. de. (1962). Die aanvang van die protestantse filosofie in Duitsland. Teologiese Studies, 18(3), 68-83. 
Vollrath, Ernst (1962). Die Gliederung der Metaphysik in eine metaphysica generalis und eine metaphysica specialis. Zeitschrift für philosophische Forschung, 16(2), 258-284.

Weber, Emil (1907). Die philosophische Scholastik des deutschen Protestantismus im Zeitalter der Orthodoxie. Leipzig: Quelle \& Meyer.

Wolff, Christian (1630). Philosophia prima sive ontologia, methodo scientifica pertractata, qua omnis cognitionis humanae principia continentur. Frankfurt - Leipzig: Renger.

Wundt, Max (1939). Die deutsche Schulmetaphysik des 17. Jhs. Tübingen: J. C. B. Mohr.

Zimmermann, Albert (1966). Allgemeine Metaphysik und Teilmetaphysik nach einem anonymen Kommentar zur aristotelischen Ersten Philosophie aus dem 14. Jahrhundert. Archiv für Geschichte der Philosophie, 48(1-3), 190-206.

Zimmermann, Albert (1998). Ontologie oder Metaphysik? Die Diskussion über den Gegenstand der Metaphysik an 13. und 14. Jahrundert: Texte und Untersuchungen: 2. erweiterte Auflage. Leuven: Peters.

Francisco Suárez's Influence on Protestant Scholasticism

Josip Talanga*

\section{Summary}

Francisco Suárez's Metaphysical Disputations achieved incredible success, his popularity being especially great in Protestant countries. Though he was influenced by Melanchthon, the influence of the Humanists and Ramus was predominant in his early period; however, in the late 16th and early 17th centuries, Protestant universities saw a renewal of the Aristotlean tradition. After the first German edition of Suárez's Metaphysical Disputations in 1600, Calvinist and Lutheran philosophers opened themselves up completely to Jesuit metaphysics. Without Suárez's influence, the Protestant Schulmetaphysic is unthinkable. The main reason for such a reception was the need for metaphyics in theological discussion. Luther's principle sola scriptura was sufficient for a strength of faith, but theological controversies sought speculative arguments. Suárez's handbook of metaphysics, with its rationality and clarity, imposed itself upon all Christian confessions as a good starting point for discussion. Under the influence of Suárezian ideas, Calvinists Rudolf Göckel and Clemens Timpler established an epistemologically oriented metaphysics which dealt primarly with the thinkable as thinkable, whereby being is equated to the thinkable. On the other hand, Christoph Scheibler's influence upon the Lutheran tradition was crucial, for it understood metaphysics as the science of being as being with an epistemologically justified division of being into real, ideal and transcendental. Multiple variations of these two positions have become typical for the German Schulmetaphysik.

Key words: Protestant scholasticism, Schulmetaphysik, Francisco Suárez, ontology, history of metaphysics, 16th century, 17th century

* Josip Talanga, Ph.D., Full Professor, Faculty of Philosophy and Religious Studies, University of Zagreb. Address: Jordanovac 110, 10000 Zagreb, Croatia. E-mail: j.talanga@ffrz.hr 